\title{
PROFIL DESA PAKRAMAN BULIAN
}

Oleh:

I Wayan Rai, dkk

Fakultas Olahraga dan Kesehatan, Universitas Pendidikan Ganesha, Singaraja

\begin{abstract}
Abstrak
Program IPTEKSS bagi Masyrakat (IbM) di Kecamatan Kubutambahan, Kabupaten Buleleng tahun 2011 yang mengambil lokasi pelaksanaan kegiatan di Desa Bulian bertujuan untuk membuat sebuah buku profil tentang Desa Pakraman Bulian. Desa Pakraman Bulian merupakan wadah sosio-religius umat Hindu yang terangkum dalam aktivitas tata palemahan, pawongan, dan parahyangan. Ketiga aktivitas ini telah berlangsung dengan baik sehingga perlu dilestarikan keberadaannya. Dalam tata palemahan misalnya, geliat pertumbuhan penduduk dapat memberikan ekses negatif bagi terjadinya alih fungsi lahan pertanian menyebabkan hilangnya sekaa subak akan berakibat pada hilangnya Dugul atau Pura Ulun Carik. Tata Pawongan di Desa Pakraman Bulian menunjukkan bahwa Desa Pakraman Bulian hanya didukung oleh lima banjar adat. Dengan jumlah krama yang relatif banyak, hal ini merupakan tantangan sekaligus peluang bagi eksistensi desa pakraman. Sementara itu, tata parahyangan di Desa Pakraman Bulian telah tertata dengan baik. Hal ini ditunjukkan dengan adanya pemetaan yang jelas mengenai kahyangan yang diempon serta tata cara upacara dan upakara yang mesti dilaksanakan.
\end{abstract}

Kata-kata kunci: desa pakraman, palemahan, pawongan, parahyangan

\section{A. PENDAHULUAN}

Desa pakraman pada hakikatnya dibentuk dan ditentukan dari tradisitradisi yang hidup dan berkembang di masing-masing wilayah tertentu. Mengingat sistem dan struktur masyarakat Hindu Bali terbentuk dan tersusun dalam desa pakraman. Seperti dijelaskan dalam Perda Nomor 03 Tahun 2001 Propinsi Bali bahwa Desa Pakraman adalah kesatuan masyarakat hukum adat di Propinsi Bali yang mempunyai satu kesatuan tradisi dan tata krama pergaulan hidup masyarakat umat Hindu secara turun-temurun dalam ikatan Kahyangan Tiga (Kahyangan Desa) yang mempunyai wilayah tertentu dan harta kekayaan sendiri serta berhak mengurus rumah tangga sendiri. Konsep senada juga tertuang dalam Perda Nomor 06 Tahun 1986 tentang konsepsi desa adat.

Dari kedua Perda ini, paling tidak dapat ditemukan enam unsur pokok yang membentuk desa adat atau desa pakraman, yaitu (1) kesatuan masyarakat hukum adat 
di Propinsi Bali, (2) mempunyai satu kesatuan tradisi dan tata krama pergaulan hidup masyarakat umat Hindu secara turun temurun, (3) dalam ikatan Kahyangan Tiga (Kahyangan Desa), (4) mempunyai wilayah tertentu, (5) mempunyai harta kekayaan sendiri, dan (6) berhak mengurus rumah tangganya sendiri.

Dari keenam unsur tersebut dapat dipahami bahwa sistem sosial masyarakat Bali adalah bercorak Hinduistis. Hal ini, juga ditegaskan oleh Sirtha (dalam Astra, 2003: 71) bahwa agama Hindu yang dianut oleh masyarakat Bali memberikan corak yang khas bagi desa pakraman. Kegiatan masyarakat adat dijiwai oleh agama Hindu yang dimanifestasikan dalam pemujaan kepada Tuhan Yang Maha Esa. Kahyangan Tiga atau Kahyangan Desa sebagai tempat pemujaan menjadi simbol pemersatu bagi masyarakat adat dalam melaksanakan upacara pemujaan sebagai wujud bhakti kepada Tuhan Yang Maha Esa. Di samping itu, Geriya (2000:63) juga menjelaskan bahwa dasar-dasar pokok sistem sosial kemasyarakatan orang Bali bertumpu pada empat landasan utama, yaitu kekerabatan, wilayah, agraris, dan kepentingan khusus. Ikatan kekerabatan telah membentuk sistem kekerabatan dan kelompok-kelompok kekerabatan. Sistem kekerabatan masyarakat Bali umumya berlandaskan prinsip patrilineal. Kelompok-kelompok kekerabatan merentang dari unit terkecil, yaitu keluarga inti, meluas ke unit menengah keluarga luas, sampai dengan klan patrilineal. Ikatan kesatuan wilayah terwujud dalam bentuk komunitas desa adat atau pakraman dengan subsistemnya, yakni banjar. Di bidang kehidupan agraris berkembang organisasi subak, sedangkan ikatan kelompok-kelompok kepentingan khusus terwujud menjadi organisasi sekaa.

Dalam pelaksanaannya, aktivitas di desa pakraman diatur berdasarkan awig-awig desa pakraman. Menurut Sirtha (dalam Astra, 2003), substansi awig-awig desa pakraman dijiwai oleh agama Hindu yang merupakan penjabaran dari falsafah Tri Hita Karana, yaitu (1) parahyangan sebagai konkretisasi pemujaan kepada Ida Sang Hyang Widhi Wasa dalam wujud upacara keagamaan, (2) pawongan sebagai perwujudan hubungan manusia dengan sesamanya dalam melaksanakan berbagai kegiatan sosial budaya, dan (3) palemahan atau wilayah berupa perwujudan hubungan manusia dengan alam yang menjadi tempat pemukiman dan menjadi sumber kehidupan masyarakat. Jadi, sistem sosial kemasyarakatan dalam masyarakat Hindu di Bali dibangun di atas kerangka Tri Hita Karana yang terdiri atas tiga gatra, yaitu parhyangan, pawongan, dan palemahan. Hal ini ditegaskan dalam patitis lan pamikukuh awig-awig desa pakraman di Bali. 
Ini menegaskan bahwa desa pakraman merupakan satu kesatuan yang harmonis dari tiga gatra, yaitu krama desa sebagai gatra pawongan membutuhkan ruang untuk melaksanakan aktivitasnya berupa kewajiban hidup (dharma) di wilayah desa pakraman, yaitu gatra palemahan. Hal ini merupakan suatu kenyataan bahwa manusia adalah bagian dari alam sehingga manusia mempengaruhi alam dan sebaliknya alam mempengaruhi kehidupan manusia. Dikatakan pula bahwa manusia dapat mempengaruhi, bahkan mengubah lingkungannya. Oleh karena itu antara krama desa dengan alam lingkungan desanya terdapat satu jalinan yang satu sama lain saling mempengaruhi. Sebaliknya, krama desa sebagai makhluk sosial membutuhkan jalinan komunikasi yang harmonis untuk memenuhi kepentingan bersama dalam suasana yang nyaman dan aman. Selain itu, dikatakan oleh Mircea Eliade (1987) bahwa manusia juga merupakan makhluk religius sehingga membutuhkan kebahagiaan batin (rohaniah). Untuk memperoleh dan memenuhi kebutuhan akan kebahagiaan yang bersifat rohaniah ini manusia berpaling dan berlindung serta bersujud ke hadapan Tuhan Yang Maha Esa. Oleh karena itu, manusia (krama desa) mendirikan tempat-tempat suci (pura) untuk memuja Tuhan (Sang Hyang Widhi Wasa), yaitu gatra parhyangan.

Agama Hindu dan sistem budaya atau adat istiadat telah menyatu dalam kehidupan masyarakat Hindu di Bali yang digunakan sebagai pedoman berperilaku. Keterpaduan antara agama Hindu dan kebudayaan Bali dapat pula diamati dari sistem sosial kemasyarakatan orang Bali dan tujuan hidupnya. Dalam hal ini tampak dalam jalinan antara Tri Hita Karana sebagai landasan sistem sosial kemasyarakatan dan tujuan hidup yang berdasarkan pada Catur Purusa Artha. Pada kenyataannya dalam kehidupan empiris sehari-hari telah pula terwujud keselarasan antara harmoni Tri Hita Karana dengan realisasi Catur Purusa Artha, baik dalam pikiran, perkataan, maupun tindakan yang pada akhirnya dipahami, dihayati, diamalkan, dan mengejawantah dalam kehidupan sebagai yadnya.

Upacara keagamaan sebagai salah satu implementasi dari yadnya dalam masyarakat Hindu di Bali senantiasa terikat dalam suatu sistem religi dan sistem sosial yang sama walaupun secara garis besarnya terdapat lima jenis yadnya (Panca Yadnya). Sistem religi yang dimaksud seperti dijelaskan oleh Koentjaraningrat (1987) terdiri atas beberapa komponen, yaitu keyakinan, ritus dan upacara, peralatan ritus dan upacara, dan umat agama yang berkaitan erat satu sama lain dan saling pengaruh mempengaruhi dan baru mendapat sifat keramat yang mendalam apabila dihinggapi 
oleh komponen utama, yaitu emosi keagamaan. Artinya, jenis upacara keagamaan (yadnya) yang dilaksanakan oleh masyarakat (umat Hindu di Bali) dilandasi oleh kayakinan keagamaan, dilaksanakan dalam bentuk kegiatan upacara, menggunakan peralatan (upakara), dipimpin oleh seorang pemimpin upacara (sulinggih), dilaksanakan di suatu tempat (tempat suci: pura, merajan, natah, bale, dll), dan disertai dengan emosi keagamaan. Dalam prosesi upacara keagamaan selalu diiringi dengan unsur kesenian, baik seni tabuh, seni tari maupun seni tembang sehingga kegiatan upacara tersebut menjadi semakin kusuk.

Entitas budaya lokal selama ini memang menjadi kekuatan Bali untuk menarik para wisatawan, domestik maupun mancanegara. Bali terkenal dengan kebudayaannya yang unik dan khas karena tumbuh dari jiwa agama Hindu, yang tidak dapat dipisahkan dari keseniannya, dalam masyarakat yang berciri sosial religius (Mantra, 1996: 2). Ini menegaskan bahwa seni, budaya, dan agama Hindu adalah satu kesatuan yang membangun kebudayaan Bali secara utuh dan menyeluruh. Berkaitan dengan hal tersebut, Geriya (dalam Ashrama,ed., 2004: 42) menyatakan bahwa dalam masyarakat Bali seni dimaknai sebagai simbol jati diri, media ekspresivitas, acuan peradaban, kreasi persembahan, akumulasi nilai tambah secara sosial-ekonomis. Selain itu, juga kesenian Bali mempunyai relasi dengan agama, lembaga sosial, sistem ekonomi (agraris, pariwisata, kerajinan, dll), sistem ekologi, dan politik.

\section{B. MATERI DAN METODE}

Metode pelaksanaan kegiatan yang diterapkan dalam pembuatan buku profil ini adalah dengan melakukan wawancara langsung kepada para tokoh prajuru Desa Pakraman Bulian untuk menggali langsung informasi sebagai sumber data primer yang akan digunakan sebagai materi dalam penyusunan buku ini. Selain melalui wawancara langsung, pencarian data dilakukan dengan teknik kajian pustaka yaitu dengan mencari data sekunder dari lontar-lontar yang terkait dengan keberadaan Desa Pakraman Bulian. Adapun langkah-langkah yang dilakukan dalam pelaksanaan kegiatan ini adalah sebagai berikut.

1) Rapat persiapan dan orientasi yang melibatkan tim IbM, pakar dan partisipan kolaboratif (Perbekel, Kelian Desa Pakraman, Kelian Banjar Adat, Prajuru Desa Pakraman Kepala Dusun dan Tim penyusun dari Desa Bulian yang di SK-kan oleh Perbekel Desa Bulian).

2) Penyusunan instrumen-instrumen penjaringan data secara partisipatif 
3) Pendampingan pendataan partisifatif mengenai hal-hal yang berkaitan dengan profil desa pakraman Bulian, seperti:

a) Sejarah Desa Bulian

b) Hukum adat/awig-awig dan kesepakatan/perarem baik tertulis maupun yang tidak tertulis

c) Pranata dan penyelenggaraan prosesi keagamaan, kegiatan adat/sosial

d) Struktur dan komposisi masyarakat adat

e) Wilayah atau wewidangan desa pakraman

f) Harta kekayaan desa pakraman

4) Penyusunan Buku Profil Desa Pakraman Bulian dan Buku Profil Pura-Pura Tua di Desa Bulian secara partisifatif kolaboratif

5) Editing buku-buku yang tersusun dan percetakan serta pengusulan ISBN

6) Pengenalan dan launcing buku Profil Desa Pakraman Bulian pada salah satu event penting di Desa Bulian

7) Rapat Evaluasi dan refleksi pelaksanaan pembelajaran tindakan berbasis proyek kolaboratif yang melibatkan semua komponen yaitu tim IbM, perbekel, Kelian Desa Pakraman sehingga disepakati sebuah sistem penyelenggaraan dokumentasi Desa Pakraman Bulian yang mendukung pelestarian tradisi, adat dan budaya Bali.

\section{HASIL DAN PEMBAHASAN}

Hasil-hasil yang dicapai selama dan setelah selesainya kegiatan IbM ini adalah tersusunnya sebuah buku profil Desa Pakraman Bulian. Dalam buku ini secara garis besar dapat dibagi menjadi enam bab, yaitu:

a. Bab 1, Pendahuluan

Pada bab 1 diuraikan secara ringkas tentang definisi serta peraturan pemerintah terkait Desa Pakraman

b. Bab 2, Gambaran Umum Desa Pakraman Bulian

Pada bab 2 diuraikan secara ringkas terkait dengan sejarah Desa Pakraman Bulian, lambang Desa Pakraman Bulian, awig-awig Desa Pakraman Bulian, Visi Desa Pakraman Bulian, Struktur prajuru Desa Pakraman Bulian.

c. Bab 3, Palemahan

Pada bab 3 diuraikan tentang wilayah desa Pakraman Bulian diantaranya kondisi geografis Desa Pakraman Bulian, luas lahan dan penggunaannya, 
kondisi lingkungan hidup, tata ruang Desa Pakraman, tanah druwen desa dan legalitasnya.

d. Bab 4, Pawongan

Pada bab 4 diuraikan tentang kependudukan, lembaga adat dan sosial lainnya serta aktivitas pasukadukaan.

e. Bab 5, Prahyangan

Pada bab 5 diuraikan tentang profil pura khayangan desa menyangkut tentang tatanan pelaksanaan upacara yang berlangsung di pura setempat.

f. Bab 6, Penutup

Pada bab 6 diuraikan tentang kesimpulan dari pembahasan yang menjadi fokus kegiatan yang dilakukan.

Kegiatan P2M ini telah berlangsung dengan baik sesuai dengan rencana dan tujuan yang telah ditetapkan. Keberhasilan dari kegiatan ini terlihat dari faktor pendukung pelaksanaan yaitu (a) antusias dari para prajuru desa yang terlibat dalam penyusunan buku profil ini, (b) respon positif dari masyarakat Desa Pakraman Bulian yang dapat menjadikan Buku profil ini sebagai pegangan ke depan dalam hidup bermasyarakat khususnya dalam kehidupan beragama.

\section{SIMPULAN}

Sebagai simpulan dalam kegiatan ini dapat disampaikan bahwa pelaksanaan program IbM di di Desa Bulian pada tahun 2011 telah berhasil dalam hal menyusun sebuah buku profil Desa Pakraman Bulian yang nantinya diharapkan dapat dijadikan sebuah pegangan oleh segenap warga Desa Pakraman Bulian dalam segala aktifitas kehidupan yang berlangsung di desa setempat.

Beberapa dampak dan manfaat yang dihasilkan oleh pelaksanaan program IPTEKS bagi masyarakat (IbM) ini tersusunnya sebuah buku profil Desa Pakraman Bulian yang dapat dibaca dan dimiliki oleh setiap anggota masyarakat desa. Dengan adanya buku ini segala informasi terkait dengan desa pakraman bisa diketahui dengan mudah oleh segenap warga masyarakat. Dengan tahu tentang desa sendiri diharapkan akan dapat menimbulkan kecintaan terhadap budaya serta keunikan tradisi agama Hindu yang berkembang di desa setempat. 


\section{E. UCAPAN TERIMA KASIH}

Atas suksesnya pelaksanaan program IbM Kecamatan Kubutambahan di Desa Bulian, maka melalui tulisan ini saya sampaikan ucapan terima kasih yang sebesarbesarnya kepada: 1) DP2M DIKTI atas dukungan dana dan kepercayaannya sehingga program dapat berjalan dengan baik ; 2) LPM Undiksha yang telah mendukung kegiatan ini ; 3) Kelian Desa Pakraman Bulian ; 4) Perbekel Desa Bulian ; 4) para prajuru Desa Pakraman Bulian ; 5) seluruh lapisan masyarakat Desa Bulian.

\section{F. DAFTAR PUSTAKA}

(1). Ashrama,ed., Berata. 2004. Ajeg Bali Sebuah Cita-Cita. Denpasar: Pustaka Bali Post

(2). Astra, I Gde Semadi, Aron Meko Mbete, Ida Bagus Puja Astawa, dan I Nyoman Darma Putra, 2003, Guratan Budaya Dalam Perspekti Multikultural: Katurang ri Kalaning Purnabakti Prof. Dr. I Gusti Ngurah Bagus, Denpasar: Program Studi Magister dan Doktor Kajian Budaya, Linguistik, dan Jurusan Antropologi, Fakultas Sastra dan Budaya Universitas Udayana.

(3). Cendikiawan, I Nyoman. 2006. Eksistensi Lembaga Perkreditan Desa (LPD) Desa Pakraman Mas Ubud Gianyar (Studi Potensi dan Kendala). Denpasar: Program Magister Ilmu Agama dan Kebudayaan, UNHI Denpasar.

(4). Couteau, Jean. 1999. Museum Puri Lukisan. Ubud: Yayasan Ratna Wartha.

(5). Geriya, I Wayan. 2000. Transformasi Kebudayaan Bali Memasuki Abad XXI. Denpasar: Dinas Kebudayaan Bali.

(6). Bagus, Sugiasta I Gusti. 2002. Katuturan Jro Pasek Bulian. Singaraja: Gedong Kirtya.

(7). Koentjaraningrat. 1987. Sejarah Teori Antropolgi I. Jakarta: Universitas Indonesia Pers.

(8). Mantra, Ida Bagus. 1996. Landasan Kebudayaan Bali. Denpasar: Yayasan Dharma Sastra.

(9). Peraturan Daerah Provinsi Bali Nomor 03 Tahun 2001 Tentang Desa Pakraman

(10). Pitana, I Gde. 1994. Dinamika Masyarakat Dan Kebudayaan Bali. Denpasar: BP.

(11). Prasasti Bulian. 